\title{
Methanol content in grape and fruit brandies: a major indicator for authenticity and safety
}

\section{Dimitar Dimitrov, Tatyana Yoncheva, Vanyo Haygarov}

\author{
Institute of Viticulture and Enology, Department of Enology and Chemistry, \\ Pleven, Bulgaria
}

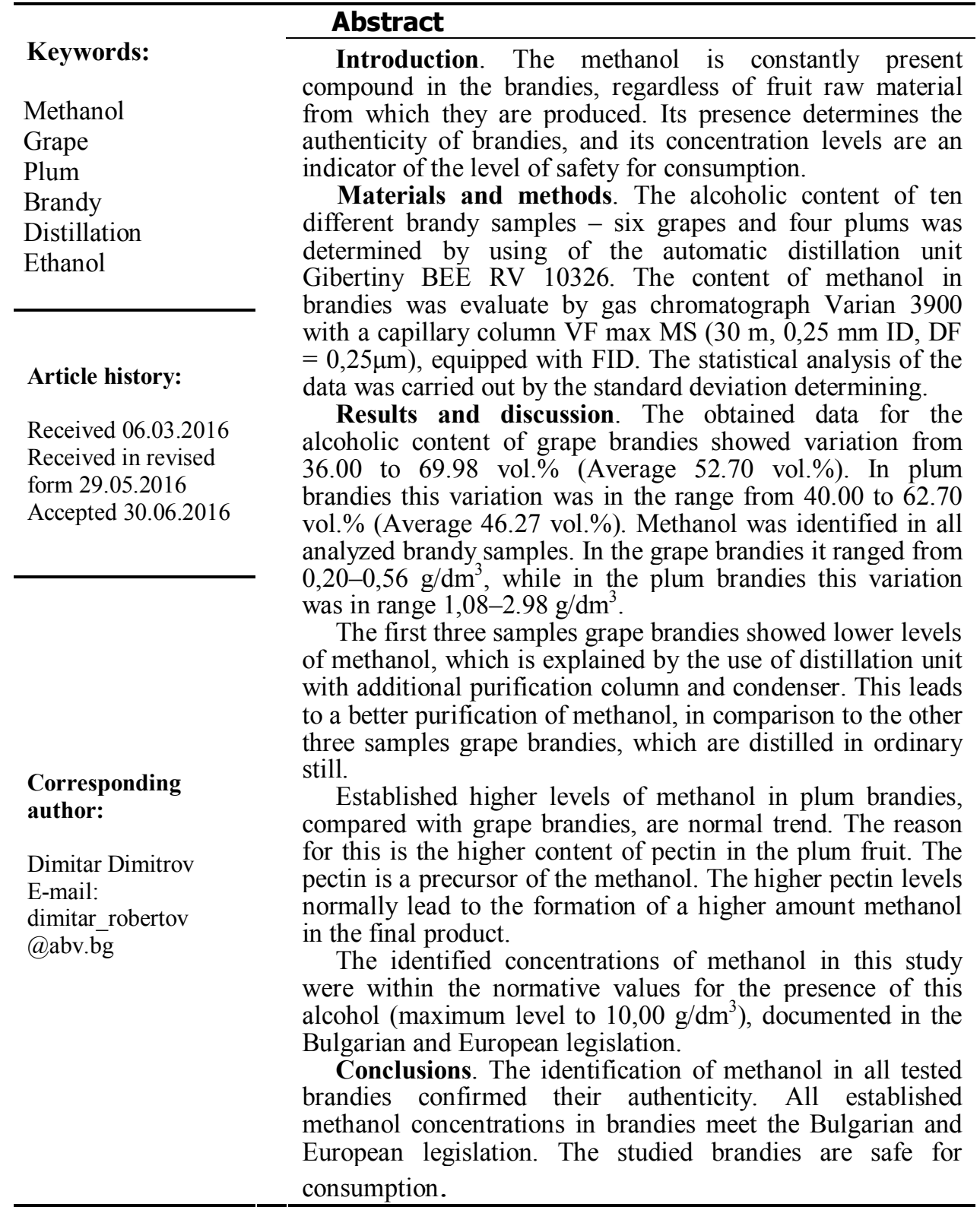




\section{Introduction}

Brandies are alcoholic drinks produced by the method of distillation of fermented fruit pastes, fruit juices, or by-products of wine production [1]. Typical indicator of their authenticity is the presence of alcohol fermentation products.

The methanol is constantly present component of brandies, regardless of the raw material from which they are produced [2]. Its presence is due to the concentration level of its precursor (pectin) in fruits, the degree of the carboxyl groups methoxylation of the pectin, the degree of rotting of the fruit and the concentration and activity of fruit enzyme systems [1]. The presence of methanol in the brandies is indicator of their authenticity and safety for consumption. The methanol is formed on the base of several enzymatic transformations following order: initial decomposition of insoluble protopectin to soluble pectin under the action of the enzyme protopectinase; subsequent decomposition of the soluble pectin to polygalacturonic acid and methanol under the action of the pectinesterase enzyme [1, 3, 4, 5]. The toxic effect which possess methanol on the human body is associated with ingesting it at high concentration and due to its highly toxic end metabolic products - formaldehyde and formic acid $[6,7,8,9]$. Poisoning with methanol can cause metabolic disorders, blindness, neurological dysfunction, surrogate toxicity and death [10, 11]. This requires constant and regulated control of its presence in alcoholic beverages and complience to defined legally-regulated limits of its presence in alcoholic beverages.

Velkov [4] claimed that the concentration of methanol in grape brandies ranges from $0.40-2.00 \mathrm{~g} / \mathrm{dm}^{3}$, for plum brandies (manufactured by qualitative, technological mature and healthy material) this range is within $2.00-5.00 \mathrm{~g} / \mathrm{dm}^{3}$, while in the plum brandies obtained after the fermentation of partially rotten (unhealthy) plums, these levels rise and fall in the range of 4.00-10.00 g/ $\mathrm{dm}^{3}$. According to Marinov [1], the methanol in grape brandies made from quality material is moving in the range $1.60-1.80 \mathrm{~g} / \mathrm{dm}^{3}$ and must not exceed 2.00 $\mathrm{g} / \mathrm{dm}^{3}$. In fruit brandies produced from healthy fruits, the methanol content varied in higher concentration range $-2.00-6.00 \mathrm{~g} / \mathrm{dm}^{3}$, while when using of rotten fruit material, it rises and falls in the range of $4.00-12.00 \mathrm{~g} / \mathrm{dm}^{3}$.

The requirements of the Bulgarian legislation on the composition of various types brandies produced in the territory of Bulgaria are defined in the Law on wine and alcoholic beverages (Law on Wine and Alcohol Beverages, Bulgaria, 2014). It confirms the following maximum levels of methanol in different groups brandies: wine brandy - a minimum alcohol content -37.5 vol. $\%$, the maximum allowed content of methanol -200 $\mathrm{g} / \mathrm{hl}$ a.a. $\left(2 \mathrm{~g} / \mathrm{dm}^{3}\right)$; grape brandy - a minimum alcohol content - $40 \mathrm{vol} . \%$, the maximum allowed content of methanol $-1000 \mathrm{~g} / \mathrm{hl}$ a.a. $\left(10 \mathrm{~g} / \mathrm{dm}^{3}\right)$; fruit brandy - the minimum alcohol content -37.5 vol. $\%$, the maximum permitted methanol content $-1000 \mathrm{~g} / \mathrm{hl}$ a.a. (10 $\left.\mathrm{g} / \mathrm{dm}^{3}\right)$.

The European legislation (Regulation № 110/2008 of the European Parliament and Council) [13] determines the maximum methanol content of fruit brandies to $1000 \mathrm{~g} / \mathrm{hl}$ a.a. $\left(10 \mathrm{~g} / \mathrm{dm}^{3}\right)$, but a slightly higher methanol levels for various fruit brandies are eligible. For brandies made from plums, apples, pears, raspberries, blueberries, apricots and peaches are allowed methanol concentrations to $1200 \mathrm{~g} / \mathrm{hl}$ a.a. $\left(12 \mathrm{~g} / \mathrm{dm}^{3}\right)$. For brandies made from currants, blackberries, elderberries, quince and juniper are allowed methanol content to $1350 \mathrm{~g} / \mathrm{hl}$ a.a. $\left(13.50 \mathrm{~g} / \mathrm{dm}^{3}\right)$.

The aim of this study is to examine the methanol content of various grape and fruit brandies and to evaluate their authenticity and safety. 


\section{- Food technologies_—}

\section{Materials and methods}

Origin of samples. Ten different brandy samples were provided for analysis: six grape brandies and four plum brandies. Samples were produced in the region of Pleven and Lovech, Bulgaria.

The first three grape brandy samples were obtained after distillation in still equipped with additional purification column, followed by condenser. The other three grape brandy samples were obtained after distillation in ordinary still. Plum brandies were obtained after distillation of fermented raw material in ordinary still too.

Determination of alcohol content. The alcohol content of the tested drinks was defined by specialized equipment with high precision - automatic distillation unit Gibertiny BEE RV 10326 (Gibertiny Electronics Srl., Milano, Italy) and Gibertiny Densi Mat CE AM 148 (Gibertiny Electronics Srl., Milano, Italy).

Determination of methanol in brandies by GC-FID. The methanol content was determined by Method IS 3752:2005 (Indian Standard 3752:2005. Alcohol Drinks Methods of Test) by preparing a standard solution. An amount of 1,0 $\mathrm{g}$ of methanol (purity $99.9 \%$, Merck, Germany) was diluted to $100 \mathrm{ml}$ with $40 \%$ ethanol solution. $10 \mathrm{ml}$ of this solution was diluted to $100 \mathrm{ml}$ with $40 \%$ ethanol solution. From this stock solution was prepared the standard methanol solution by adding $5 \mathrm{ml}$ of the diluted solution in the $10 \mathrm{ml}$ test tube, and adding $1 \mathrm{ml}$ of the previously prepared solution of octanol (internal standard). The $2 \mu \mathrm{l}$ of resulting standard solution of methanol and octanol was injected in gas chromatograph Varian 3900 with a capillary column VF max MS (30 m, 0,25 mm ID, DF = $0,25 \mu \mathrm{m}$ ), equipped with a flame ionization detector (FID). The used carrier gas was He. Hydrogen to support combustion was generated and supplied to the chromatograph via a hydrogen generator (Parker Chroma Gas: Gas Generator 9200). The injection is manually by microsyringe.

The parameters of the gas chromatographic determination were: injector temperature $220{ }^{\circ} \mathrm{C}$; detector temperature $-250{ }^{\circ} \mathrm{C}$, initial temperature of the oven $-35^{\circ} \mathrm{C} /$ retention 1 min, rise to $55^{\circ} \mathrm{C}$ with step of $2{ }^{\circ} \mathrm{C} / \mathrm{min}$ for $11 \mathrm{~min}$, rise to $230^{\circ} \mathrm{C}$ with step of $15^{\circ} \mathrm{C} / \mathrm{min}$ for $3 \mathrm{~min}$. Total time of chromatography analysis $-25,67 \mathrm{~min}$.

Identification of methanol and octanol in the standard solution is shown in the chromatogram - figure 1.

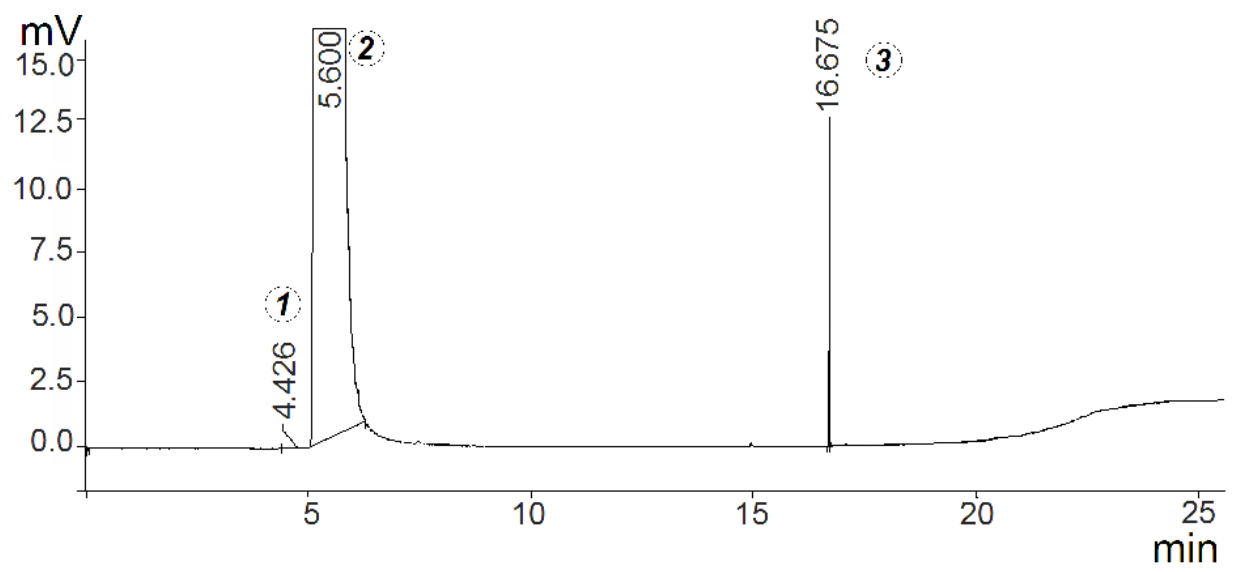

Fig. 1. Chromatogram of standard solution (methanol and octanol (IS)):

1 - methanol (retention time $=4.426 \mathrm{~min}$ ); 2 - ethanol (solvent);

3 - octanol (internal standard; retention time $=16.675 \mathrm{~min}$ ) 
After determination of the retention times of methanol and octanol, we proceed to the identification and quantification of the methanol in the brandy samples. $5 \mathrm{ml}$ of each brandy sample and $1 \mathrm{ml}$ of internal standard solution (octanol) were placed in $10 \mathrm{ml}$ test tubes with a stopper. Prepared samples were injected in an amount of $2 \mu \mathrm{l}$ in a gas chromatograph and was carried out an identification and quantification of the methanol content in each of them.

Statistical analysis. The statistical analysis of the data was carried out by determining the standard deviation (SD), with triple repetition of the analyses. It is performed with the Excel 2007 software application of the Microsoft Office 2007 suite (Microsoft Corporation, USA).

\section{Results and discussion}

The obtained data for the alcoholic content of the studied grape and fruit brandies were presented in Table 1.

The ethanol content (vol.\%) in grape brandies varied in the range of 36.00 vol.\% 69.98 vol.\% (Average 52.70 vol.\%).

Variation of ethanol in plum brandies was in the range of $40.00 \mathrm{vol} . \%-62.70 \mathrm{vol} . \%$ (Average 46.27 vol.\%). These indicators were brought to standard alcoholic content for both group brandies - grape and fruit, regulated by the Bulgarian and European legislation (Law for Wine and alcoholic drinks, 2004; Regulation №110 / 2008 of the EU).

The chromatographic profiles of the analyzed grape brandies were presented in Figures $2-7$.

Alcoholic content of the analyzed grape and fruit brandies

Table 1

\begin{tabular}{|c|c|}
\hline Brandy sample & $\begin{array}{c}\text { Content of ethanol, } \\
\text { vol.\% }\end{array}$ \\
\hline Grape brandy 1 & 68.70 \\
\hline Grape brandy 2 & 69.98 \\
\hline Grape brandy 3 & 45.62 \\
\hline Grape brandy 4 & 40.20 \\
\hline Grape brandy 5 & 36.00 \\
\hline Grape brandy 6 & 55.70 \\
\hline Plum brandy 1 & 40.00 \\
\hline Plum brandy 2 & 62.70 \\
\hline Plum brandy 3 & 36.70 \\
\hline Plum brandy 4 & 45.68 \\
\hline
\end{tabular}



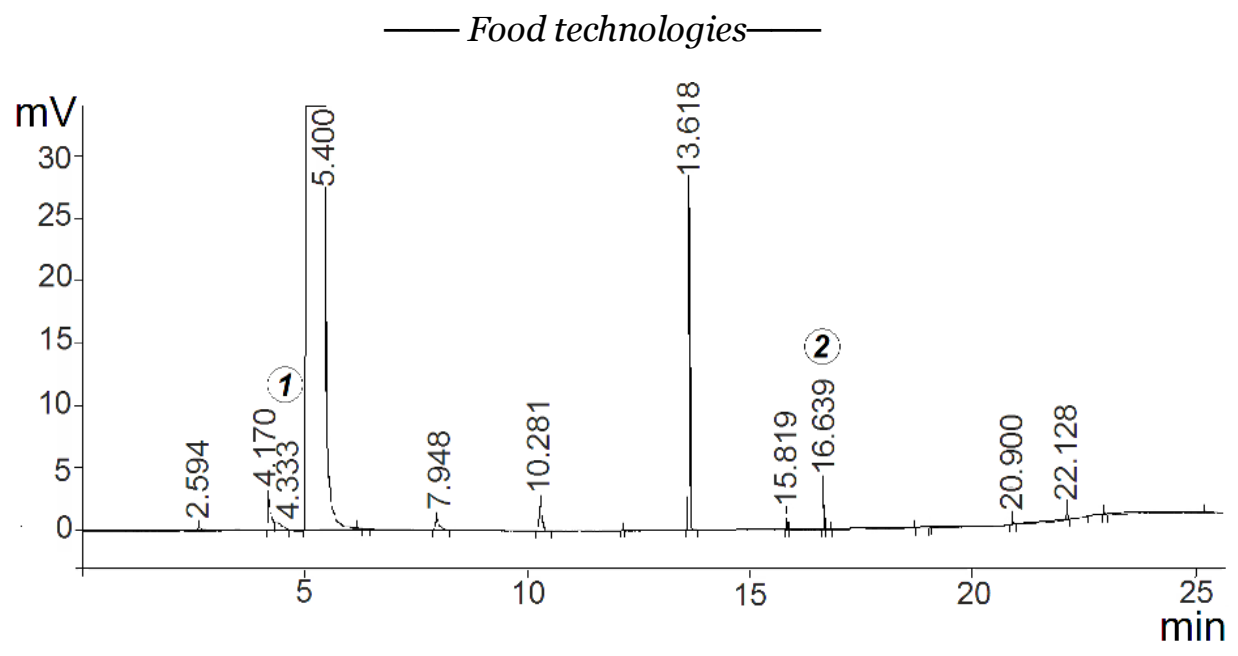

Fig. 2. Chromatographic profile of grape brandy 1:

1- methanol (retention time $=\mathbf{4 . 3 3 3} \mathrm{min}$ );

$2-$ octanol (internal standard; retention time $=16.639 \mathrm{~min}$ )

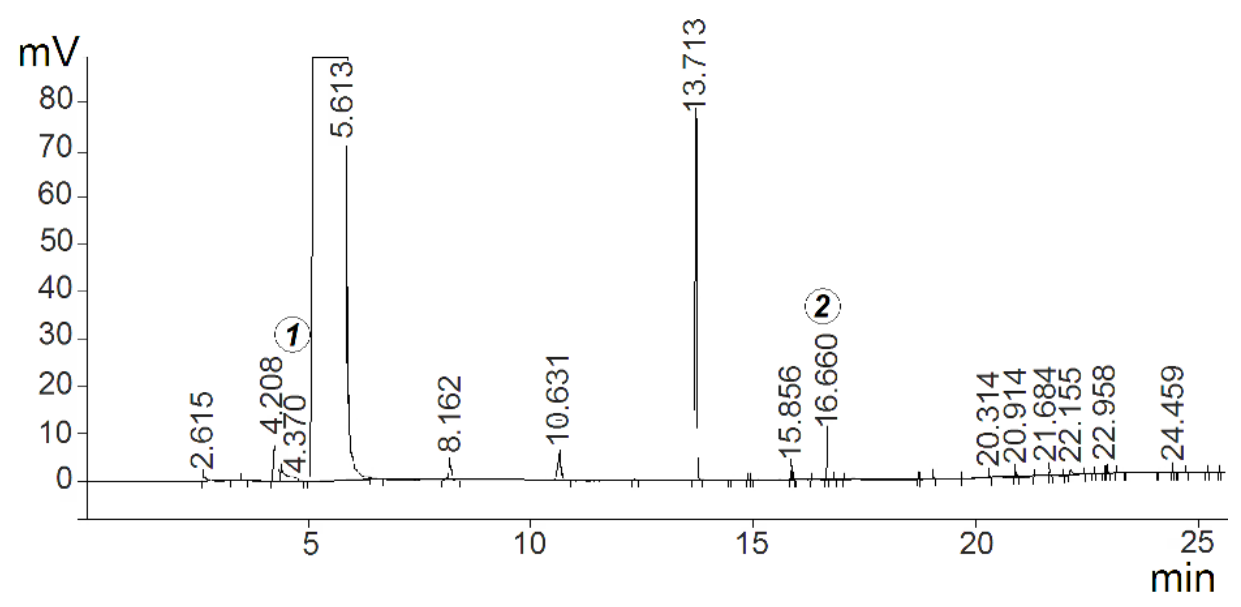

Fig. 3. Chromatographic profile of grape brandy 2:

1- methanol (retention time $=\mathbf{4 . 3 7 0} \mathbf{~ m i n})$;

$2-$ octanol (internal standard; retention time $=16.660 \mathrm{~min}$ ) 


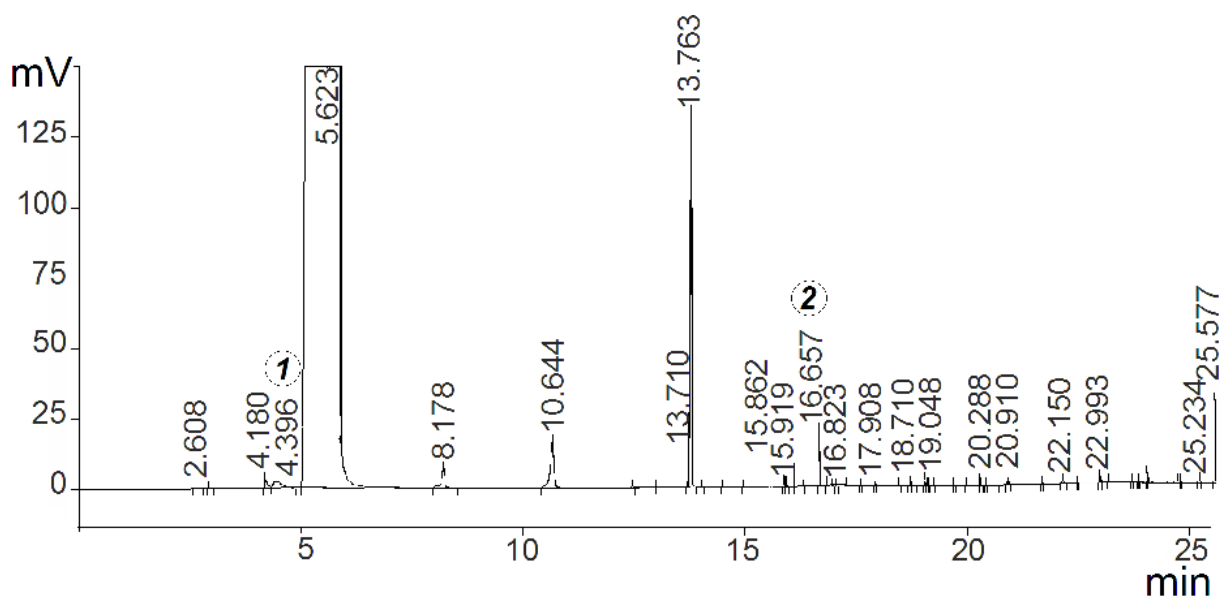

Fig. 4. Chromatographic profile of grape brandy 3:

1- methanol (retention time $=\mathbf{4 . 3 0 6} \mathbf{m i n}$ );

$2-$ octanol (internal standard; retention time $=\mathbf{1 6 . 6 5 7} \mathrm{min}$ )

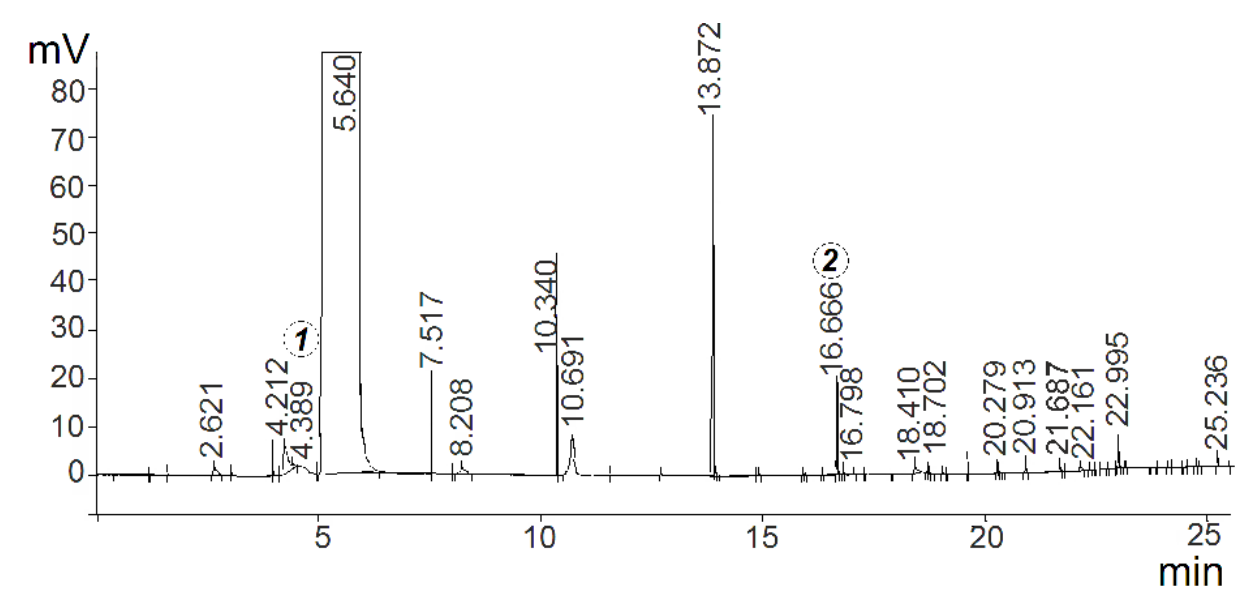

Fig. 5. Chromatographic profile of grape brandy 4:

1- methanol (retention time $=\mathbf{4 . 3 8 9} \mathrm{min}$ );

$2-$ octanol (internal standard; retention time $=16.666 \mathrm{~min}$ ) 


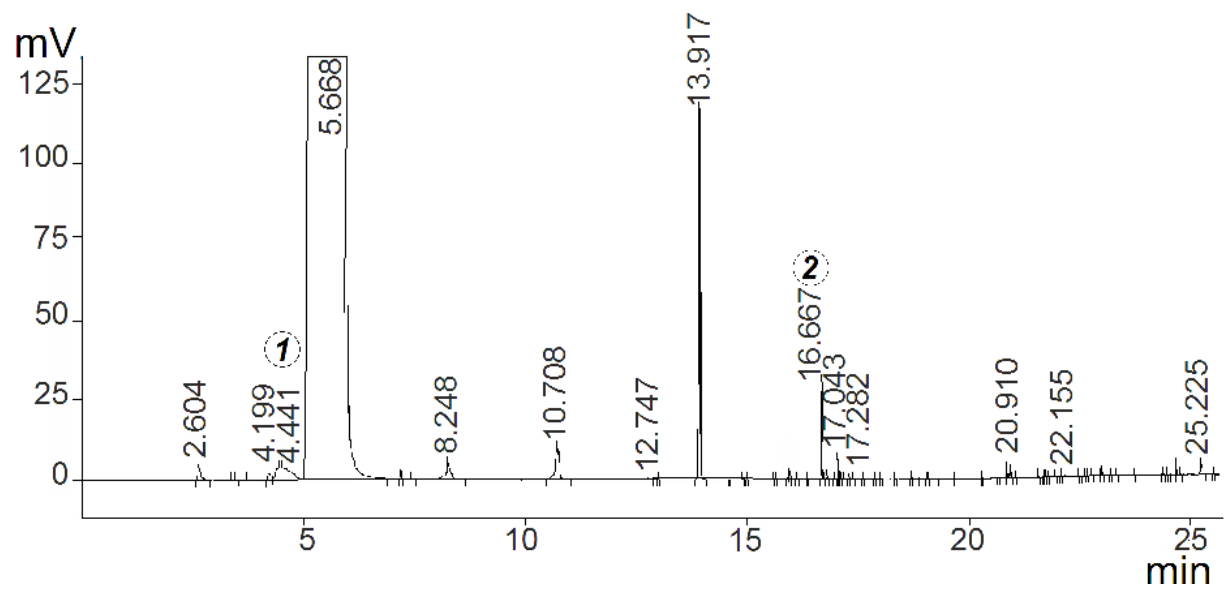

Fig. 6. Chromatographic profile of grape brandy 5:

1- methanol (retention time $=4.441 \mathrm{~min})$;

$2-$ octanol (internal standard; retention time $=\mathbf{1 6 . 6 6 7} \mathrm{min}$ )

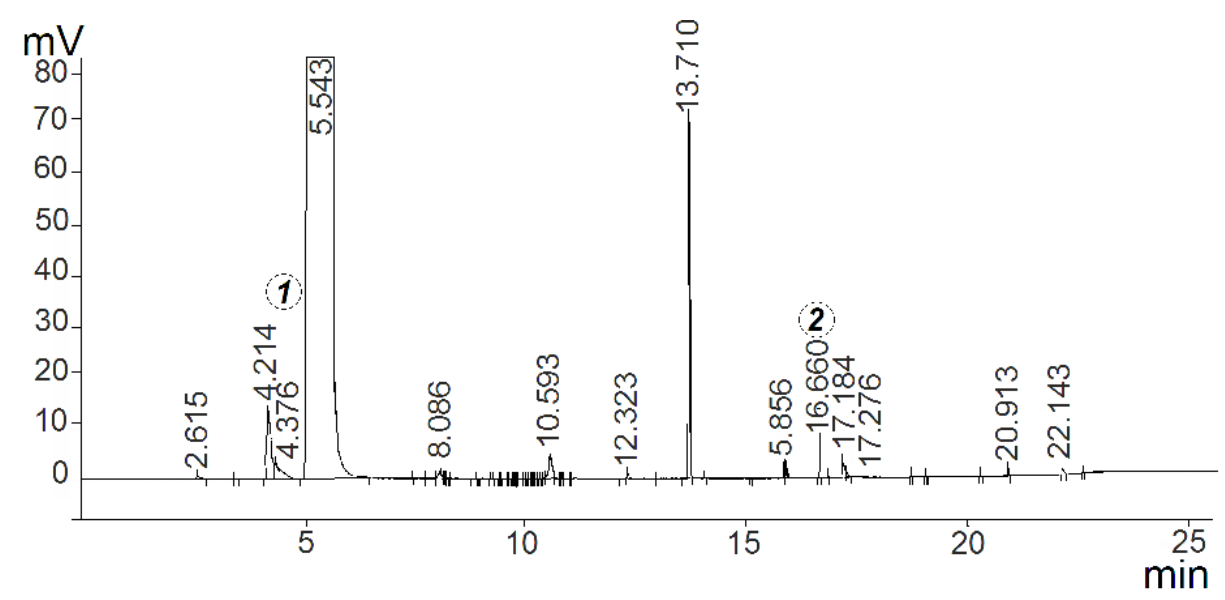

Fig. 7. Chromatographic profile of grape brandy 6:

1- methanol (retention time $=\mathbf{4 . 3 7 6} \mathrm{min})$;

$2-$ octanol (internal standard; retention time $=16.660 \mathrm{~min}$ )

The identification of methanol and octanol in brandy samples was performed according to established retention times of the two compounds in the standard solution. As is apparent from the chromatographic profiles, the methanol was identified in all six samples. This is an evidence that the samples were authentic grape brandies, made from grape raw material on the base of fermentation process. The presence of methanol in these samples exclude the possibility that they were falsified. The evidence supporting this proposition was the presence of other peaks were not identified, but indicated presence of other compounds that are likely to be products of the yeast metabolism. 
The established concentration levels of methanol in grape brandies are presented in table 2 .

Methanol content of studied grape brandies

Table 2

\begin{tabular}{|c|c|}
\hline Brandy sample & $\begin{array}{c}\text { Content of methanol, } \\
\mathbf{g} / \mathbf{d m}^{\mathbf{3}}\end{array}$ \\
\hline Grape brandy 1 & $0.20 \pm 0.03$ \\
\hline Grape brandy 2 & $0.27 \pm 0.01$ \\
\hline Grape brandy 3 & $0.30 \pm 0.02$ \\
\hline Grape brandy 4 & $0.56 \pm 0.01$ \\
\hline Grape brandy 5 & $0.39 \pm 0.01$ \\
\hline Grape brandy 6 & $0.59 \pm 0.02$ \\
\hline
\end{tabular}

It is noteworthy that the first three grape brandies showed lower methanol content than the other three. This is due to various distillation plants, on the basis of which brandies were obtained. The use of distillation in stills equipped with additional purification column and condenser for the first three samples resulted in better cleaning. This reflected in decreased methanol content in them.

The obtained results indicate the highest content of methanol in grape brandy $6-0.59 \pm$ $0.02 \mathrm{~g} / \mathrm{dm}^{3}$. The lowest found methanol level occurred in grape brandy $1-0.20 \pm 0.03$ $\mathrm{g} / \mathrm{dm}^{3}$. The obtained data correlate with the values documented in the scientific works of Marinov [1] and Velkov [4]. The methanol content was in agreement with the requirements of the Bulgarian and European legislation. The obtained results for the content of methanol in analyzed grape brandies were clear evidence for their authenticity. The concentrations of methanol indicate that these brandies were harmless from a toxicological point of view, with acceptable levels of methanol.

The chromatographic profiles of the second studied group brandies - plum, were presented in figures 8-11.

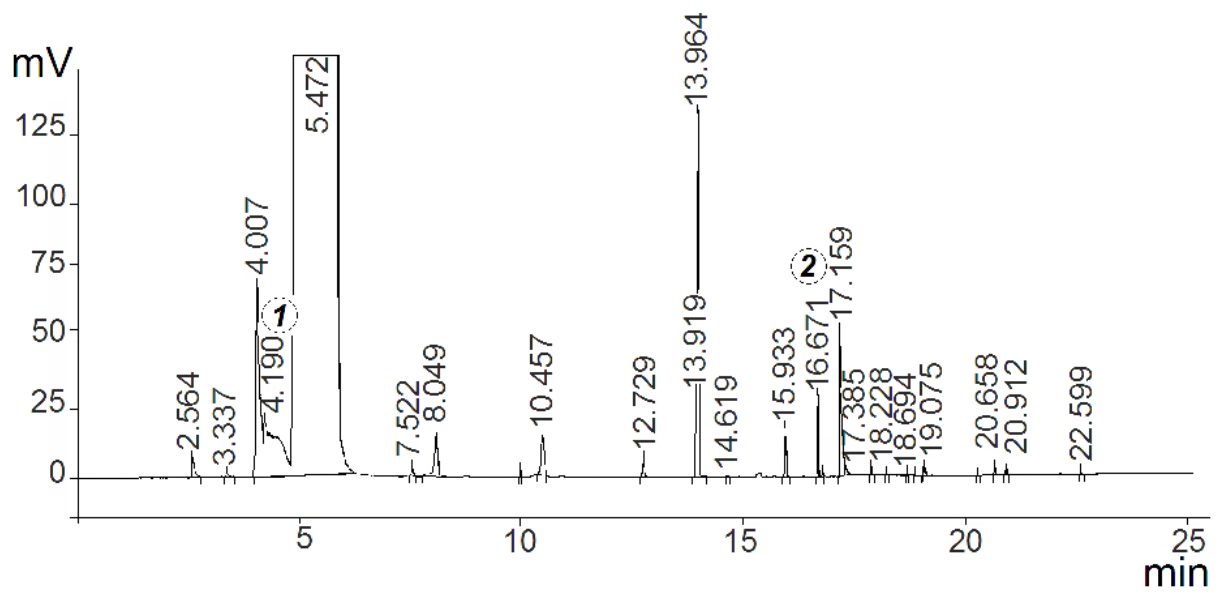

Fig. 8. Chromatographic profile of plum brandy 1:

1- methanol (retention time $=\mathbf{4 . 1 9 0} \mathrm{min}$ );

$2-$ octanol (internal standard; retention time $=16.671 \mathrm{~min}$ ) 


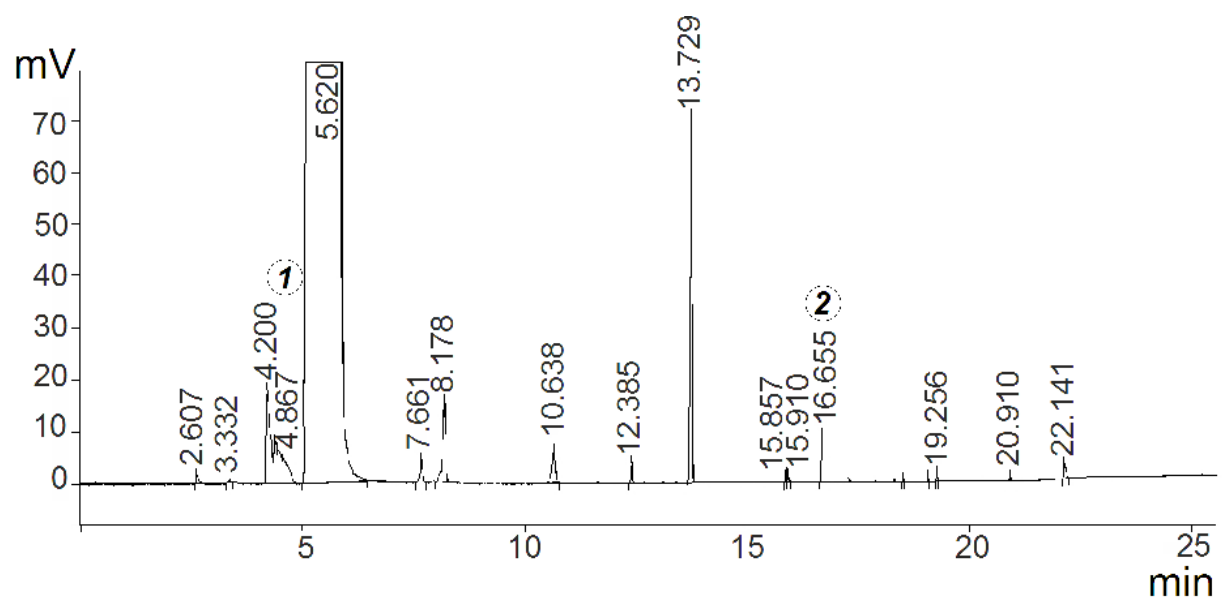

Fig. 9. Chromatographic profile of plum brandy 2:

1- methanol (retention time $=\mathbf{4 . 3 6 7} \mathrm{min}$ );

$2-$ octanol (internal standard; retention time $=16.655 \mathrm{~min}$ )

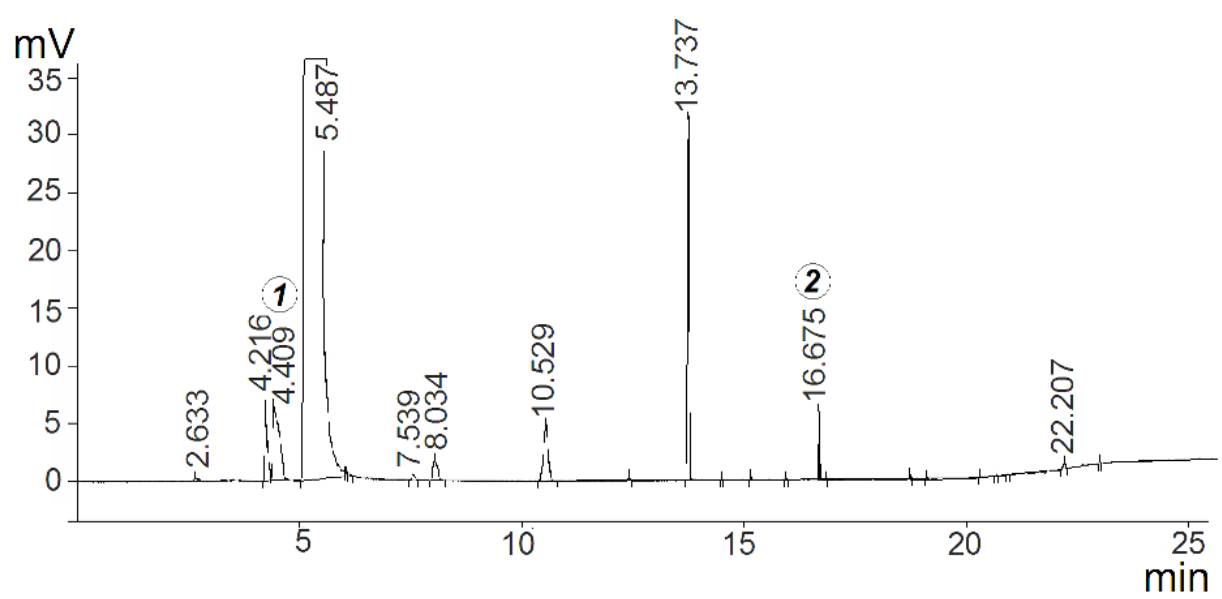

Fig. 10. Chromatographic profile of plum brandy 3:

1- methanol (retention time $=\mathbf{4 . 4 0 9} \mathrm{min}$ );

$2-$ octanol (internal standard; retention time $=16.675 \mathrm{~min}$ )

The chromatographic profiles of brandies made from plum raw material, indicated the presence of methanol in all four tested brandies. This proves the authenticity of beverages. A comparison between the chromatographic profiles of the grape and plum brandies showed that the peaks of methanol in plum brandies occupy a larger area - an indicator of a higher amount of searched congener. The quantities of methanol in plum brandies, presented in table 3 , confirm this clear trend. 


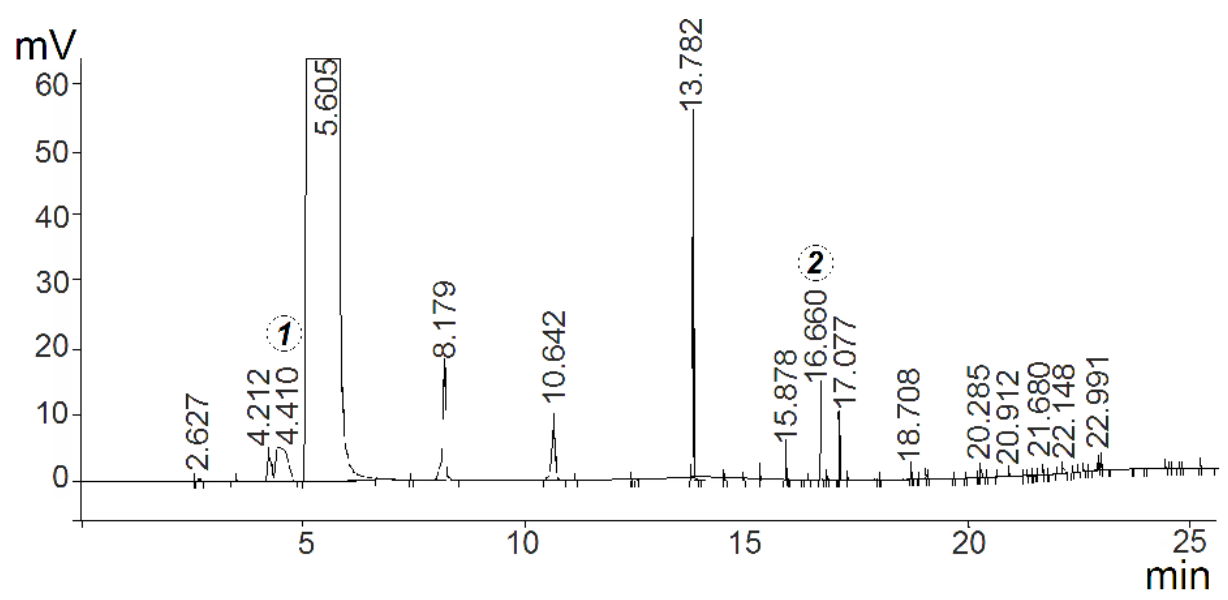

Fig. 11. Chromatographic profile of plum brandy 4:

1- methanol (retention time $=\mathbf{4 . 4 1 0} \mathrm{min})$;

$2-$ octanol (internal standard; retention time $=16.660 \mathrm{~min}$ )

Content of methanol in plum (fruit) brandies

Table 3

\begin{tabular}{|c|c|}
\hline Plum brandy & $\begin{array}{c}\text { Content of methanol, } \\
\mathbf{g} / \mathbf{d m}^{\mathbf{3}}\end{array}$ \\
\hline Plum brandy 1 & $2.98 \pm 0.02$ \\
\hline Plum brandy 2 & $1.64 \pm 0.03$ \\
\hline Plum brandy 3 & $2.36 \pm 0.01$ \\
\hline Plum brandy 4 & $1.08 \pm 0.01$ \\
\hline
\end{tabular}

The presence of higher amounts methanol in plum brandies against the grape brandies, is a normal trend. This is for the reason that plum fruits has a higher content of pectin, which is a precursor for the formation of methanol. Higher pectin levels normal lead to higher amounts of methanol in the final product. The highest methanol content was found in plum brandy $1-2.98 \pm 0.02 \mathrm{~g} / \mathrm{dm}^{3}$. In all samples the methanol content was within the range of $1.00-5.00 \mathrm{~g} / \mathrm{dm}^{3}$, which indicated that the used raw material was strong, quality and technologically mature and the distillation process was carried out in compliance with the technology of distillation. The identified concentrations of methanol in plum brandies categorize them as safe, because they cover the normative values for the presence of this alcohol (maximum acceptable levels to $10.00 \mathrm{~g} / \mathrm{dm}^{3}$ ), documented in the Bulgarian Law of wine and alcohol beverages (2014) and Reg. №110/2008 of the EU.

\section{Conclusions}

The study, undertaken in order to evaluate the degree of authenticity and safety of six samples grape brandies and four samples plum brandies found: 
1. Identification of methanol in all analyzed brandy samples, which confirms their authenticity and proves that they are made from raw material typical for them;

2. Established quantitative data for the presence of methanol confirm the identity of brandies corresponded to the raw material used for its production. The methanol content in brandies complied to the limits of this alcohol in both groups brandies grape and fruit (plum);

3. The reported higher levels of methanol in plum brandies were indicator for their authenticity, because plum fruits are rich source of the methanol precursor - pectin;

4. All established methanol amounts in brandies meet the legal requirements, which is a direct confirmation for their safety consumption.

\section{References}

1. Marinov M. (2005), Technology of alcoholic beverages and spirit, Academic Publishing of University of Food Technologies, Plovdiv, p. 343.

2. Jung A., Jung H., Anwarter V., Pollak St., Farr A., Hecser L., Schiopu A. (2010), Volatile congeners in alcoholic beverages: analysis and forsenic significance, Romanian Journal of Legal Medicine, XVIII, pp. 265-270.

3. Coldea T., Socacin C., Dan Vadnar M. (2011), Gas-chromatographic analysis of major volatile compounds found in traditional fruit brandies from Transylvania, Romania, Not. Bot. Horti. Agrobo., 39(2), pp. 109-116.

4. Velkov E. (1996), Encyclopedia of alcoholic beverages, "Poligrafia" Ltd., Plovdiv.

5. Lukic I., Milicevic B., Banovic M., Tomas S., Radeka S., Persuric D. (2011), Secondary aroma compounds in fresh grape marc brandies as a result of variety and corresponding production technology, Food Technology Biotechnology, 49(2), pp. 277-293.

6. Skrzydlewska E. (2003), Toxicological and metabolic consequences of methanol poisoning, Toxicol. Mech. Methods, 13(4), pp. 277-293.

7. Cleland J.G., Kingsbury G.L. (1977), Multimedia environmental goals for environmental assessment, MS Environmental Protection Agency, publication no. 600/7-77-1366, pp. 24-450.

8. Nicholls P. (1976), The effect of formate on cytochrome aa3 and on electron transport in the intact respiratory chain, Biochim. Biophys. Acta, 430, pp. 13-29.

9. Shahangian S., Ash K.O. (1986), Formic and lactic acidosis in a fatal case of methanol intoxication, Clinnical Chemistry, 32, pp. 395-397.

10. Kruse J.A. (1992), Methanol poisoning, Intensive Care Medicine, 18(7), pp. 391-397.

11. Lachenmeier D.W., Rehm J., Gmel G. (2007), Surrogate alcohol: what do we know and where do we go, Alcohol Clin. Exp. Res., 31, pp. 1613-1624. 